\title{
UJI APLIKASI JAMUR BEAUVERIA BASSIANA (BALSAMO) VUILL. TERHADAP SYMPHYLID DI LABORATORIUM
}

\author{
Desye Rinche Natalia Simarmata, Lestari Wibowo \& Afandi \\ Jurusan Agroteknologi Fakultas Pertanian Universitas Lampung \\ Jl. Prof. Dr. Soemantri Brodjonegoro No. 1 Bandar Lampung 35145 \\ E-mail: desyesimarmata@yahoo.co.id
}

\begin{abstract}
ABSTRAK
Symphylid merupakan salah satu hama perusak akar pada tanaman nanas. Salah satu alternatif pengendalian hama yang terus dikembangkan yaitu dengan menggunakan jamur entomopatogen yaitu Beauveriabassiana. Tujuan penelitian ini ialah untuk mengetahui apakah jamur entomopatogen B. bassiana yang diaplikasikan mampu menginfeksi symphylid yang hidup pada tanah tanpa bahan organik maupun berbahan organik. Penelitan ini dilakukan di Laboratorium Hama Tanaman, Fakultas Pertanian, Universitas Lampung pada bulan Januari-April 2015. Penelitian ini terdiri dari dua set percobaan, yaitu aplikasi $B$. Bassiana terhadap symphylid dengan metode residu pakan dan residu pada media hidup symphylid. Masing-masing percobaan disusun dalam rancangan acak lengkap (RAL), dengan 3 perlakuan dan 10 ulangan. Seluruh data yang diperoleh diuji dengan analisis ragam dan di lanjutkan dengan pengujian BNT dengan taraf nyata $\%$. Hasil penelitian ini menunjukkan terjadinya mortalitas symphylid. Namun, mortalitas symphylid pada perlakuan aplikasi B. bassiana, baik perlakuan dimana symphylid hidup pada tanah yang berbahan organik maupun tanpa bahan organik sangat rendah. Mortalitas symphylid tertinggi pada kedua set percobaan terdapat dalam perlakuan aplikasi $B$. bassiana terhadap symphylid yang hidup pada tanah berbahan organik yaitu sebesar $10 \%$ dan6\%. Dengan demikian hasil penelitian ini belum dapat membuktikan bahwa B. bassiana secara nyata mampu menginfeksi symphylid.
\end{abstract}

Kata Kunci: Beauveria bassiana, symphylid, tanah berbahan organik

\section{PENDAHULUAN}

Nanas (Ananas comusus) merupakan salah satu tanaman hortikultura yang buahnya banyak disukai oleh masyarakat di berbagai penjuru dunia. Nanas mendominasi perdagangan buah tropika dunia sehingga nanas juga sangat berperan dalam bidang ekonomi. Produksi buah nanas mencapai 20\% dari buah tropika dunia. Berdasarkan data dari Badan Statistik Nasional pada tahun 2012, hasil produksi nanas yaitu 178. 899 ton. Indonesia merupakan negara pengekspor buah nanas, baik dalam bentuk buah nanas olahan atau buah segar (BPS, 2012).

Salah satu perusahaan di Indonesia yang memproduksi nanas olahan adalah PT Great Giant Pineaple (PT GGP) yang terletak di Provinsi Lampung. PT GGP telah mengekspor nanas ke lebih dari 50 negara dan mensuplai 15-20\% total kebutuhan nanas dunia. Produk nanas kaleng PT GGP semuanya diekspor, 40 $\%$ diantaranya ke Eropa, $35 \%$ ke Amerika Utara dan $25 \%$ lainnya ke Asia Pasifik. Perkebunan nanas milik PT GGP, saat ini hampir mencapai 500. 000 ton nanas segar per tahun. Perkebunan nanas di PT GGP merupakan perkebunan nanas terbesar di dunia dan menjadi produsen utama nanas olahan di Indonesia (Oviana, 2013).

Pemanfaatan lahan secara intensif untuk tanaman semusim sepanjang tahun, Karama et al. (1990) menyatakan untuk mempertahankan kandungan bahan organik tanah perlu diimbangi dengan pemberian pupuk organik yang memadai. Tanpa bahan organik, kesuburan tanah akan menurun meskipun pupuk anorganik diberikan dengan takaran tinggi. Oleh sebab itu, pertanaman nanas membutuhkan tanah dengan aerasi dan drainase yang baik, serta mengandung humus.

Selain itu, adanya organisme pengganggu tanaman (OPT) menjadi salah satu kendala dalam budidaya pertanaman nanas. Akhir-akhir ini PT GGP melakukan pemberian bahan organik yang tinggi untuk pertanaman nanas. Permasalahan muncul ketika terdapat kerusakan pada akar tanaman nanas dalam jumlah yang tinggi. Lisdiana dan Soemadi (1997) melaporkan tanaman nanas memiliki perakaran sedikit dan dangkal serta peka terhadap penggenangan. Adanya kerusakan pada akar tanaman nanas ini disebabkan oleh symphylid.

Symphylid merupakan artropoda yang hidup di tanah. Serangan symphylid yang terjadi pada akar tanaman nanas di tandai dengan gejala "witches broom" 
atau dikenal dengan sapusetan. Daun menjadi berwarna merah dan semakin lama tanaman aka menjadi kerdil dan mati. Hal ini menyebabkan kerugian besar bagi PT GGP, sehingga dilakukan pengendalian symphylid dengan fumigant dan pestisida kimia. Salah satu alternatif untuk mengurangi penggunaan insektisida sintetik dalam mengendalikan populasi hama adalah mengunakan agensia hayati berupa jamur entomopatogen. Salah satu agensia hayati yang berpotensi pengendalian hama tanaman perkebunan adalah jamur entomopatogen $B$. bassiana. Mandal et al. (2003) menggungkapkan di dalam tubuh inangnya jamur ini akan memperbanyak diri hingga seluruh jaringan serangga terinfeksi. Serangga yang telah terinfeksi $B$. bassiana biasanya akan berhenti makan, sehingga menjadi lemah, dan akhirnya mengalami kematian. Serangga yang mati tidak selalu disertai gejala pertumbuhan spora. Secara umum jamur entomopatogen membutuhkan lingkungan yang lembab untuk dapat menginfeksi serangga.

Thomas 1997 dalam Prayogo (2006) menyebut kanada dua cara pathogen untuk masuk ke dalam tubuh serangga, yaitu ketika inang menelan pathogen selama proses makan, dan ketika pathogen masuk melalui penetrasi langsung pada kutikula serangga. Pernyataan ini didukung oleh Plate (1976) bahwa mekanisme infeksi yang dilakukan $B$. bassiana dimulai dari melekatnya konidia pada kutikula serangga, kemudian berkecambah dan tumbuh di dalam tubuh inangnya. Symphylid juga merupakan hewan artropoda yang mempunyai kutikula sehingga memiliki kesamaan dengan serangga. Oleh karena itu, B. bassiana diharapkan berpotensi sebagai agensia hayati hama symphylid.

\section{BAHAN DAN METODE}

Penelitan ini dilaksanakan Laboratorium Hama dan Penyakit Tanaman, Fakultas Pertanian, Universitas Lampung. Symphylid sebagai hama uji dalam penelitian ini diperoleh dari kebun nanas milik PT Great Giant Pineapple (GGP) Kecamatan Terbanggi Besar Kabupaten Lampung Tengah. Penelitian ini dilaksanakan pada bulan Januari-April 2015. Penelitian ini terdiri dari 2 set percobaan, yaitu aplikasi B. bassiana terhadap symphylid dengan metode residu pakan dan metode residu pada media hidup symphylid. Masingmasing percobaan disusun dalam Rancangan Acak Lengkap (RAL) yang terdiri dari 3 perlakuan dan 10 ulangan sehingga terdapat 30 satuan percobaan.

Penelitian ini dilakukan dengan 3 tahap, yaitu tahap pertama symphylid diperoleh dengan cara manual, yaitu menggali tanah kebun nanas pada lokasi kebun yang lembab dan pernah tergenang (perairan drainasenya yang kurang baik) sedalam $10-15 \mathrm{~cm}$ dengan menggunakan sekop kecil. Kegiatan ini dilakukan di perkebunan nanas milik PT GGP Lampung Tengah. Jumlah symphylid yang diperlukan untuk persiapan penelitian ini berkisar 300 ekor. Tahap kedua yaitu perbanyakan jamur $B$. bassiana, yaitu isolat $B$. bassianayang akan diuji dalam penelitian ini berasal dari UPTD Balai Perlintanbun, Lampung. Kemudian dilakukan isolasi untuk mempertahankan isolat murni. Isolasi dilakukan di Laboratorium Penyakit Tumbuhan Fakultas Pertanian Universitas Lampung dengan menggunakan media Potato Dextrose Agar (PDA) dan media jagung yang di inkubasi selama \pm 2 minggu.

Selanjutnya tahap ketiga yaitu pengujian $B$. Bassiana pada symphylid dan pengamatan. Seluruh data yang diperoleh di uji dengan analisis sidik ragam dan dilanjutkan dengan pengujian BNT dengan taraf nyata $5 \%$.

\section{HASIL DAN PEMBAHASAN}

Hasil penelitian uji aplikasi jamur B. bassiana dengan metode residu pakan terhadap symphylid di laboratorium menunjukkan terjadinya mortalitas pada symphylid. Data mortalitas symphylid selengkapnya tertera pada Tabel 1. Hasil pengamatan menunjukkan terjadi mortalitas symphylid pada perlakuan aplikasi $B$. bassiana, baik perlakuan dimana symphylid hidup pada tanah yang berbahan organik maupun tanpa bahan organik. Namun, mortalitas symphylid yang terjadi sangat rendah. Sedangkan pada kontrol tidak terdapatsymphylid yang mengalami kematian sampai pengamatan pada 20 hari setelah aplikasi.

Hasil pengujian statistik sidik ragam ternyata menunjukkan aplikasi $B$. bassiana tidak berpengaruh nyata terhadap mortalitas symphylid. Mortalitas symphylid tertinggi terdapat pada perlakuan aplikasi $B$. bassiana terhadap symphylid yang hidup pada tanah berbahan organik yaitu sebesar $10 \%$. Sedangkan aplikasi B. Bassiana terhadap symphylid yang hidup pada tanah tanpa bahan organik mortalitas hanya sebesar $8 \%$.

Hasil penelitian uji aplikasi jamur $B$. bassiana dengan metode tanah media hidup symphylid di laboratorium menunjukkan terjadinya mortalitas pada symphylid. Namun, mortalitas symphylid yang terjadi pada perlakuan aplikasi $B$. bassiana, baik perlakuan dimana symphylid hidup pada tanah yang berbahan organik maupun tanpa bahan organik sangat rendah. Data mortalitas symphylid selengkapnya juga tertera pada Tabel 1. Hasil pengujian statistik sidik ragam ternyata menunjukkan aplikasi $B$. bassiana tidak berpengaruh nyata terhadap mortalitas symphylid. 
Mortalitas symphylid tertinggi terdapat pada perlakuan aplikasi $B$. bassiana terhadap symphylid yang hidup pada tanah berbahan organik yaitu sebesar $6 \%$. Sedangkan aplikasi $B$. bassiana terhadap symphylid yang hidup pada tanah tanpa bahan organik mortalitas hanya sebesar 4\%. Sedangkan pada kontrol tidak ada symphylid yang mengalami kematian sampai pengamatan pada 20 hari setelah aplikasi.

Symphylid yang mengalami kematian, tubuhnya cepat mengalami kehancuran sehingga sulit untuk dideteksi penyebab kematiannya. Gambar 1 menunjukkan telur symphylid dan symphylid yang mengalami kematian. Dengan demikian dari penelitian ini belum dapat membuktikan bahwa B. bassiana secara nyata mampu menginfeksi symphylid. Symphylid yang tidak mengalami kematian, sampai pada pengamatan 20 hari setelah aplikasi terlihat bergerak aktif dan mengalami pergantian kulit (molting). Beberapa ekor symphylid pada semua perlakuan menghasilkan telur dan berkembangbiak. Telur symphylid diletakkan secara berkelompok pada rongga tanah. Jumlah telur perkelompok berkisar antara 5-7 butir.

Dinata (2006) menyatakan bahwa B. bassiana efektif untuk mengendalikan semut api, aphid, dan ulat grayak Spodoptera exigua. Sedangkan pada penelitian kali ini isolat jamur B. Bassiana yang digunakan berasal dari hama padi, sehingga isolat yang digunakan belum efektif menginfeksi symphylid. Selain itu, keadaan suhu dan kelembaban di laboratorium tempat penelitian dilakukan yang kurang sesuai untuk pertumbuhan $B$. bassiana sehingga menyebabkan rendahnya mortalitas pada symphylid. Untuk perkecambahan dan proses infeksi B. bassiana membutuhkan suhu dan kelembaban tertentu. Jamur entomopatogen B. bassiana mampu berkembang pada kisaran suhu $5-35^{\circ} \mathrm{C}$ (Burges and Hussey, 1971) dengan kelembaban di bawah 80-100\%

Tabel 1. Persentase mortalitas symphylid 20 hari pengamatan aplikasi B. bassiana dengan metode residu pakan.

\begin{tabular}{|c|c|c|c|c|c|c|c|c|c|}
\hline \multirow[t]{2}{*}{ Perlakuan } & \multicolumn{4}{|c|}{$\begin{array}{l}\text { Mortalitas symphylid dengan } \\
\text { metode residu pakan }(\%)\end{array}$} & \multirow[t]{2}{*}{ Perlakuan } & \multicolumn{4}{|c|}{$\begin{array}{l}\text { Mortalitas symphylid dengan metode } \\
\text { residu tanah media hidup symphylid (\%) }\end{array}$} \\
\hline & $5 \mathrm{hsa}$ & $10 \mathrm{hsa}$ & $15 \mathrm{hsa}$ & $20 \mathrm{hsa}$ & & $5 \mathrm{hsa}$ & $10 \mathrm{hsa}$ & $15 \mathrm{hsa}$ & $20 \mathrm{hsa}$ \\
\hline $\mathrm{KP}$ & 0 & 0 & 0 & 0 & KM & 0 & 0 & 0 & 0 \\
\hline $\mathrm{BP}$ & 4 & 4 & 8 & 10 & $\mathrm{BM}$ & 0 & 2 & 4 & 6 \\
\hline $\mathrm{TP}$ & 2 & 4 & 6 & 8 & $\mathrm{TM}$ & 0 & 0 & 2 & 4 \\
\hline F-hit & $1,08^{\mathrm{tn}}$ & $1,13^{\text {tn }}$ & $1,56^{\mathrm{tn}}$ & $2,42^{\text {tn }}$ & F-hit & - & $1,00^{\operatorname{tn}}$ & $1,08^{\mathrm{tn}}$ & $1,13^{\text {tn }}$ \\
\hline
\end{tabular}

Keterangan: tn-menunjukan F-hit perlakuan pada percobaan ini tidak berpengaruh nyata terhadap mortalitas symphylid pada sdidik ragam taraf $5 \%$. Hsa $=$ Hari setelah aplikasi, $\mathrm{KP}=$ Tanpa aplikasi $B$. bassiana, $\mathrm{BP}=$ Aplikasi $B$. bassiana dengan metode residu pakan terhadap symphylid yang hidup pada tanah berbahan organik di laboratorium, TP = Aplikasi $B$. bassiana dengan metode residu pakan terhadap symphylid yang hidup pada tanpa bahan organik di laboratorium, $\mathrm{KM}=$ Tanpa aplikasi $B$. bassiana, $\mathrm{BM}=$ Aplikasi B. bassiana dengan metode residu pakan terhadap symphylid yang hidup pada tanah berbahan organik di laboratorium, dan TM = Aplikasi B. bassiana dengan metode residu pakan terhadap symphylid yang hidup pada tanpa bahan organik di laboratorium.

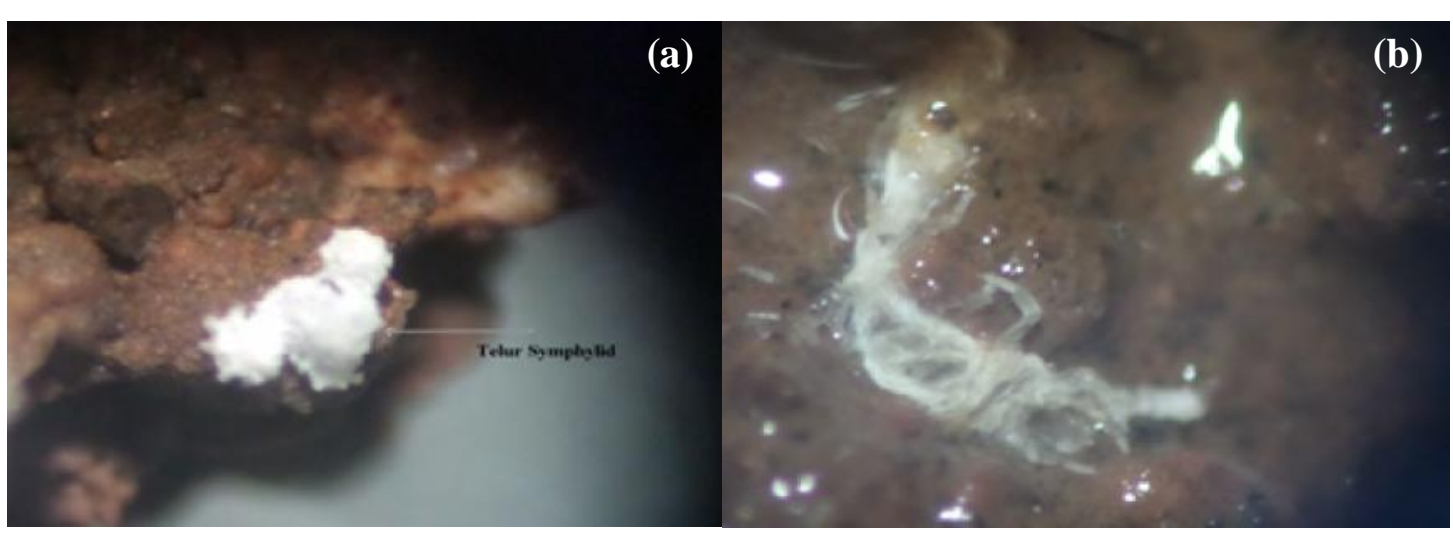

Gambar 1. Telur symphylid (a) dan symphylid yang mengalami kematian (b) 
(Storey and Gardner, 1988), sedangkan kondisi yang terjadi di laboratorium tempat penelitian dilakukan suhu berkisar $26-29{ }^{\circ} \mathrm{C}$ dengan kelembaban berkisar 50$60 \%$. Symphylid merupakan artropoda yang hidup ditanah bersifat sarofit dan omnivora yang berperan sebagai dekomposer didalam tanah. Symphylid memakan ganggang, jamur dan lumut, namun, pada periode tertentu, mereka tertarik dengan biji dan akar yang sangat muda, di mana mereka makan ekstremitas, dan dengan mengunyah akar yang lebih tua (Waterhouse, 1968). Sampai saat ini belum ada penelitian yang melaporkan kefektifan $B$. bassiana menginfeksi symphylid untuk mendukung penelitian ini.

\section{KESIMPULAN}

Berdasarkan hasil penelitian aplikasi jamur $B$. bassiana terhadap mortalitas symphylid dapat disimpulkan bahwa aplikasi jamur B. bassiana terhadap symphylid hanya menyebabkan kematian tidak lebih dari $10 \%$ dan mortalitas symphylid tidak berbeda nyata antar perlakuan. Berdasarkan percobaan yang telah dilakukan dapat disimpulkan bahwa $B$. bassiana belum terbukti mampu menginfeksi dan menyebabkan mortalitas symphylid.

\section{DAFTAR PUSTAKA}

Biro Pusat Statistik (BPS). 2012. Produksi Nanas. Tersedia: http://bps.go.id, [20 Mei 2014].

Burger, H.D. dan N.W. Hussey. 1971. Microbial Control of Insects and Mites. Academic Pres. New York.

Dinata, A. 2006. Insektisida Yang Ramah Lingkungan. Tersedia: http://www.pikiranrakyat.com. cetak/ 044/15/cakrawala.penelitian, [23 Agustus 2015].

Karama, A.S., A.R. Marzuki, dan I. Marwan. 1990. Penggunaan pupuk organik pada tanaman pangan. Prosiding Lokakarya Nasional Efisiensi Penggunaan Pupuk V. Cisarua, 1213 Nopember 1990. Puslit Tanah dan Agroklimat. Bogor. 395-425 hlm.

Lisdiana dan W. Soemadi. 1997. Budidaya Nanas, Pengolahan dan Pemasaran. Aneka. Solo. 78p.

Mandal, S.M.A., B.K Mishar, dan P.R Mishar. 2003. Efficacy and economics of some biopesticides in managing Hellicoverpa armigera (Hubner) on Chickpea. Annals of Plant Protection Sciences, 11(2): 201-203.

Oviana, T. 2013. Hubungan kondisi visual tanaman terhadap populasi symphylid dan gejala Witches Broom pada akar tanaman nanas [Ananas comosus (L) Merr]. Laporan Praktikum Umum. Universitas Lampung. Bandar Lampung.

Prayogo, Y. 2006. Upaya Mempertahankan Keefektifan Cendawan Entomopatogen Untuk Mengendalikan Hama Tanaman Pangan. Balai Penelitian Tanaman Kacang-kacangan dan Umbiumbian. Malang. $53 \mathrm{hlm}$.

Storey, K.G. and A.W. Gardner. 1988. Movement of an aqueous spray of Beauveria bassiana into the profile four Georgia Soils. Environ. Entomol. 17:135-139.

Waterhouse, J.S. 1968. Studies on tehe garden symphylan, Scutigerella Immaculata (Symphyla: Scutigerellidae). The Canadian Entomologist 100: $72-178$. 